\section{The impacts of education, vocational tenure and career opportunities on job satisfaction, organizational commitment and intent to leave: Security sector analysis}

Eğitimin, mesleki tecrübenin ve terfi imkanlarının iş tatmini, örgütsel bağl1lık ve işten ayrilma niyeti üzerine etkisi: Güvenlik sektörü analizi

\author{
Sedat Kula ${ }^{1}$ \\ Hidayet Taşdöven ${ }^{2}$ \\ Mustafa Dönmez ${ }^{3}$
}

\begin{abstract}
This study investigates whether job satisfaction, organizational commitment and turnover intention levels of four-year university graduates and two-year police vocational school graduates are different from each other. A sample of 394 police officers working in seven provinces of seven different geographical regions in Turkey was analyzed. The results of $t$ test and correlation analysis obtained indicated that the university degree holders indicated a lower level of organizational commitment and higher level of turnover intention than their non-degree holder colleagues. It was found that there is no statistically significant difference between job satisfaction levels of two groups. Career opportunities increased job satisfaction and organizational commitment while tenure reduced turnover intention. The findings of the study illustrate a need for internal policy reform in how the executives of TNP organize their employment and human resource management
\end{abstract}

\section{Özet}

$\mathrm{Bu}$ araştırmada dört ylllık üniversite eğitimi almış polis memurları (POMEM) ile iki yıllık polis meslek yüksekokulu mezunu polis memurlarının (PMYO) iş tatmini, örgütsel bağlllık ve işten ayrilma niyeti düzeylerinin farklll1k gösterip göstermediği araştırılmıstır. Türkiye'nin yedi coğrafi bölgesinde yer alan yedi ildeki POMEM ve PMYO mezunlarından alınan 394 kişilik örneklem üzerinde çalışma yapılmıştır. Elde edilen verilerin $\mathrm{t}$ testi ve korelasyon analizleri sonucunda, üniversite mezunu polis memurlarının, üniversite mezunu olmayan meslektaşlarına göre daha düşük seviyede örgütsel bağlllık gösterdikleri ve daha yüksek seviyede işten ayrılma eğilimi gösterdikleri bulunmuştur. İş tatmini açısından iki grup arasında istatistiki olarak anlamlı bir fark bulunmamıştır. Meslekte ilerleme imkânlarının iş tatmini ve örgütsel bağl1llğ1 arttı̆̆1, POMEM mezunları için meslekte geçen sürenin artması ile örgüte olan bağlllığın azaldığı tespit edilmiştir.

\footnotetext{
${ }^{1}$ Dr, Kars Emniyet Müdürlüğü, kulasedat36@gmail.com

2 Dr, Amasya Emniyet Müdürlüğü, htasdoven@gmail.com

${ }^{3}$ Dr, Diyarbakır Emniyet Müdürlügüu, mustafadonmez.tr@gmail.com
} 
Kula, S., Taşdöven, H., \& Dönmez, M. (2015). Eğitimin, mesleki tecrübenin ve terfi imkanlarının iș tatmini, örgütsel bağlllık ve işten ayrılma niyeti üzerine etkisi: Güvenlik sektörü analizi. International Journal of Human Sciences, 12(1), 129-149. doi: $10.14687 /$ ijhs.v12i1.3134

policies Based on the study results, Araştırma sonuçları insan kaynakları yönetimi ve recommendations were made on human işa alma politikaları ile ilgili politika reformu resources management policies.

Keywords: job satisfaction; organizational commitment; intent to leave; tenure; promotion opportunities; education; police

(Extended English abstract is at the end of this document) ihtiyacını ortaya koymuştur. Araştırma sonuçlanı doğrultusunda, insan kaynakları yönetim politikalarına dair önerilerde bulunulmuştur.

Anahtar Kelimeler: iş tatmini; örgütsel bağlllık; işten ayrilma niyeti; tecrübe; terfi imkanları; eğitim, polis

\section{Giriş}

Üniversite eğitiminin polisler için gerekli olup olmadığ1 dünyanın birçok ülkesinde tartışılmakta ve bazı ülkelerde polisliğe giriş için 4 yıllık üniversite bitirmiş olma şartı aranmaktadır. Üniversite eğitimini gerekli kılmayan polis teşkilatlarında da üniversite eğitimli polislerin sayısı günden güne artmaktadır. Türkiye'de üniversite mezunu polislerin oranı \% 39, ön lisans mezunu olanların oranı ise \% 46.63 tür. 2004 te 22.424 olan üniversite mezunu sayıs1 2013 yılı itibariyle 100.928 e ulaşmıştır. Bu sayılardaki artış 2000 yıllardan itibaren politika değiştirmek suretiyle üniversite mezunlarının teşkilata alınmasıyla gerçekleştirilmiştir.

Türk emniyet teşkilatının emniyet hizmetleri personeli genel anlamda amir ve memurlardan oluşmakta ve teşkilatın \% 85'ini polis memurları oluşturmaktadır. 2006 yılına kadar sadece Polis Meslek Yüksek Okullarını (PMYO) bitirenler polis memuru olabiliyordu. Bu yıldan itibaren 4 yıllık fakülte mezunlarına yönelik olarak yapılan bir sınavı başarı ile geçip Polis Meslek Eğitim Merkezleri'nde (POMEM) 6 aylık (2012 yılı itibariyle bu süre 9 aya uzatılmıştır) polislik eğitimi gören adaylar da polis memuru olabilmektedir (Güvenlik Eğitimi Araştırma Merkezi, 2011: 116). Emniyet içerisinde polis memurlarının alımı ile ilgili bu farklılık, ister istemez bu iki okul mezunlarının pek çok yönden karşılaştırılmaya tabi tutulmasına yol açmışır. POMEM mezunları, olayları nispeten hızlı kavrama ve iletişime açık olma özellikleriyle öne çıkmakla birlikte, genel olarak mesleki nitelikleri yetersiz, disiplin ve saygi konusunda eksikleri olan, asayiş hizmetlerinde isteksiz, polislik mesleğinin temel uygulamalarını yapabilme konusunda yetersiz kişiler olmakla eleştirilmektedir. PMYO mezunları ise mesleğe bağllık ve meslek heyecanı açısından daha iyi durumda olmakla birlikte, iletişim kurabilme ve halkla ilişkiler konusunda zayıf, olaylara duygusal yaklaşan ve olayları anlamakta ve anlamlandırmakta güçlük çeken sorumluluk duygusu yeterli seviyede olmayan kişiler olmakla tenkit edilmektedirler (Güvenlik Eğitimi Araştırma Merkezi, 2011: 289-294). 
Kula, S., Taşdöven, H., \& Dönmez, M. (2015). Eğitimin, mesleki tecrübenin ve terfi imkanlarının iș tatmini, örgütsel bağlllık ve işten ayrılma niyeti üzerine etkisi: Güvenlik sektörü analizi. International Journal of Human Sciences, 12(1), 129-149. doi: $10.14687 /$ ijhs.v12i1.3134

Personelin iş tatminin düşük olması ve örgüte bağlllı̆ıının azalması işten ayrılma niyetini de beraberinde getirmektedir. İşten ayrılmanın olumsuz sonuçları olduğu gibi, işten ayrılma niyetinin de bir takım olumsuz etkileri bulunmaktadır. İşten ayrıma niyetinde olan bir çalışanın işte göstermiş olduğu performansin düştüğü ve verimlilik seviyesinde azalma görüldüğü bazı çalışmalarda elde dilen bulgular arasındadır (Brough ve Frame, 2004; Cotton ve Tuttle, 1986).

Bu çalışmanın araştırma sorusu, 4 yıllık üniversite eğitiminden sonra polisliğe başvurup Polis Meslek Eğitim Merkezinden (POMEM) mezun olan ile liseden sonra polis mesleğine başvurup 2 yıllık Polis Meslek Yüksekokulunu (PMYO) bitiren polis memurlarının; iş tatmini, örgütsel bağlılık ve işten ayrılma niyetleri açısından farklı olup olmadıklarıdır. Çalışma sonuçlarının gerek bu okullardaki eğitim programlarının düzenlenmesi gerekse polis eğitim yönetiminde değişikliğe gidilmesi açısından bir fikir vereceği değerlendirilmektedir.

\section{Kaynak Taraması}

\subsection{Is Tatmini}

İş tatmini, bir işletme veya kurumda çalışan personel için doğrudan, o kurum veya işletme için ise dolaylı etkileri olan bir olgudur. İş tatmini yaşayan personelin daha yüksek kalitede iş ürettiği; buna karşın tatminsiz personelin performansının düştüğü, sık sık işe gelmeme ve geç gelme durumunun oluştuğu, ekip elemanları ile çatışma yaşadıkları bir gerçektir (Bilgin, Emhan ve Bez, 2011). Bir tanım yapmak gerekirse iş tatmini, insanların yaptıkları işi değerlendirmeleri sonucu ortaya çıkan keyifli ruh halini ifade eder (Locke, 1976).

İş tatminini belirleyen faktörler işe ve çalışılan ortama göre farklılıklar göstermekle birlikte temelde birbirleriyle benzeşirler. Bu faktörler genel olarak iş çevresi ve bireysel değişkenler olarak iki ana başlık altında incelenmektedir. İş çevresi kategorisinde çalışma ortamı, işin niteliği, iletişim, terfi, ücret ve kararlara katılma gibi faktörler sayılırken, bireysel faktörler yaş, cinsiyet, eğitim seviyesi, medeni durum, çalışma saatleri ve kişisel özelliklerdir (Jansen, Kerkstra, Abusaad ve Der Zee, 1996). Amerika Birleşik Devletleri'ndeki bir üniversitede çalışan araştırmacıların iş tatminini belirleyen faktörleri incelemek amacıyla yapılan bir anket sonuçlarına göre, araştırmacıların yaptıkları işin en tatmin edici tarafları sırasıyla; bağımsız çalışma olanağ1 (\%60), iş çeşitliliği (\%49), zor problemleri çözmek (\%46), insanın başarılı olduğu bir işi yapması (\%46) ve birlikte çalıştığ1 insanlardır (\%34). Yine aynı anket sonuçlarına göre araştırmacılar için iş tatminini azaltan faktörler sırasıyla; bürokrasinin çokluğu (\%38), personel yetersizliği (\%30), idareciler tarafindan takdir edilmeme (\%28), kariyer ilerlemesinin olmaması (\%28) ve ücret yetersizliği (\%26) konularıdır (Studt, 2005). Türkiye'de iş tatminini belirleyen faktörler genel olarak çalışma koşulları, çalışma arkadaşları, işin niteliği, yönetim ve ücret politikalarıdır (Serinkan ve Bardakçı, 2007:2). 
Kula, S., Taşdöven, H., \& Dönmez, M. (2015). Eğitimin, mesleki tecrübenin ve terfi imkanlarının iş tatmini, örgütsel bağlllık ve işten ayrılma niyeti üzerine etkisi: Güvenlik sektörü analizi. International Journal of Human Sciences, 12(1), 129-149. doi: $10.14687 /$ ijhs.v12i1.3134

\section{2. Örgütsel Bağl1l1k}

Bir organizasyonun varllğ̣1 ve devamlıllğı için en önemli unsurlardan birisi, örgütsel bağlılıktır. Üyeleri arasındaki örgütsel bağl1lı̆g yüksek olan organizasyonlarda uyum ve üretkenliğin daha yüksek, giderlerinin de daha düşük olduğu gözlemlenmektedir. Bu bağlllığ1 daha da sağlamlaştırmak için organizasyonlar meslekte ilerleme olanaklarını genişletme, ücret arttırma gibi yollara başvururlar (Bayram, 2005). Örgütsel bağll11k, genel kabul gören bir tanımlamaya göre "çalışanların örgüt amaçlarına ve değerlerine kuvvetli bir şekilde inanması ve onları kabullenmesi, örgütün amaçlarını gerçekleştirmek için yoğun çaba sarf etme isteği ve örgüt üyeliğini devam ettirebilmek için hissedilen şiddetli arzu" (Mowday, Steers ve Porter, 1979, s. 225) olarak açıklanmıştır. Bateman ve Strasser (1984-95) örgütsel bağlllı̆g, örgüt ve birey arasında var olan uyumun bir işlevi olarak tanımlamışlardır.

Örgütlerin nitelikli personeli elinde tutma adına hayati bir öneme sahip olan örgütsel bağlllığın düzeyini belirleyen faktörler, konu ile ilgilenen akademisyenler tarafindan dört temel kategori altında incelenmiştir. Yaş, cinsiyet, eğitim düzeyi gibi demografik özellikler ile başarı arzusu ve katılımcı değerler gibi iş hayatına ilişkin özellikler bireysel faktörleri; örgütün büyüklüğü, esnek çalışma saatleri, ücret sistemi gibi özellikler ise örgüt yapısına ilişkin faktörleri oluşturmaktadır. Personel-yönetici ilişkileri, örgüt iklimi ve iş tatmini gibi çalışma ortamına ilişkin faktörler ile işin içeriği, kapsamı ve rol çatışması gibi iş ve role ilişkin faktörler, örgütsel bağlıllğın düzeyini belirleyen diğer gruplar olarak incelenmiştir (Özdevecioğlu, 2003).

Örgütsel bağlılığın sonuçları üzerinde çalışanlar, özellikle iki önemli konu üzerinde odaklanmışlardır. Bunlar, işten ayrılma ya da işten ayrılma düşüncesi (Clegg, 1983) gibi olumsuz tutum ve davranışlar (Cotton ve Tuttle, 1986; Cohen 1993) ve örgütsel vatandaşlık davranışı, performans gibi yapıcı/olumlu iş davranışlarıdır (Brief ve Motowidlo, 1986; Bragger et al., 2005; LePine, Erez ve Johnson 2002).

\subsection{Iş̧ten Ayrılma Niyeti}

Özellikle 1980'li yılların başlanından itibaren pek çok araştırmacı (Peters, Bhagat ve O'connor, 1981; Kramer, Callister ve Turban, 1995; Kalliath ve Beck, 2001), insanların işlerinden neden ayrıldıkları sorusuna cevap vermeye çalışmışlardır. Ortaya çıkan sonuçlar birbirleriyle çok fazla uyumlu olmasa da genel olarak iş stresi, örgüt bağlılığının sağlam olmaması, kendini kontrol edememe ve işten tatminsizlik gibi faktörlerin personelin işi bırakmasının başlıca sebepleri olduğu iddia edilmiştir (Firth, Mellor, Moore ve Loquet, 2004). Bulunan faktörler bazı akademisyenler tarafından kişisel faktörler, iş ile ilgili faktörler, çevresel faktörler ve çalışanların uyumu olarak dört 
Kula, S., Taşdöven, H., \& Dönmez, M. (2015). Eğitimin, mesleki tecrübenin ve terfi imkanlarının iș tatmini, örgütsel bağlllık ve işten ayrılma niyeti üzerine etkisi: Güvenlik sektörü analizi. International Journal of Human Sciences, 12(1), 129-149. doi: $10.14687 /$ ijhs.v12i1.3134

ana grup altında incelenmiştir (Iverson, 1999). Bu faktörleri belirlemenin işten ayrılma oranlarını azaltmada etkili olduğu varsayılmaktadır (Maertz ve Campion, 1998).

İşten ayrılma, bir insanın gönüllü olarak veya olmayarak bir işten ayrılmasını ifade eder (Smith ve Brough, 2003). Bir başka açıdan tanımlanırsa, çalışanların şirket ve iş arasında veya iş ile işsizlik arasında bir rotasyondur (Abbasi ve Hollman, 2000). Bir iş yerinde her zaman için bir pozisyon boşalır ve boş pozisyona yeni personel atanır. İşten ayrılma bu prosedür zincirinin adıdır (Ongori, 2007). Isşten ayrılma temelde, bir örgütün üyeliğinden çalışan tarafindan başlatılan (istifa gibi) gönüllü ayrılma ve çalışan tarafından başlatılmayan (işten çıkarma, personel tasarrufuna gidilmesi ve ölüm gibi) ayrılma olarak iki şekilde olur (Price, 1977: 10-25). Isşten ayrilma niyeti ise bir personelin yakın bir gelecekte örgütten ayrılma ihtimalidir. Isşten ayrılma niyeti işten ayrılma davranışının ön habercisi olarak tanımlanır (Brough ve Frame, 2004).

Yukarıda da belirtildiği gibi insanlardaki işten ayrılma niyetini etkileyen faktörler bazı akademisyenler tarafindan dört ana kategoride incelenmektedir (Iverson, 1999). İnsanların işten ayrılmasına yol açan faktörlerden iş ile ilgili olanlar, akademisyenlerin en çok üzerinde durduğu konular olmuştur. İş ile ilgili faktörler genel olarak ekonomik nedenler (Mano ve Tzafrir, 2004), özerklik, işte tekdüzelik, adalet, duygusal olarak tükenme, diğer çalışanların desteği, yönetici desteği ve işin tehlikeleridir (Iverson, 1999). Bunlara ek olarak insanlardan beklenen davranışlarla yaptıkları davranışlar arasındaki farktan kaynaklanan rol çatışması, bir işin nasıl yapılacağı hakkında açıç̧a bilgi verilmemesi, yöneticilerin ve iş arkadaşlarının beklentilerinin ne olduğunun tam olarak anlaşılamaması, işyerinde aşırı baskı gibi sebepler de işle ilgili faktörlerdir (Guimaraes, 1997). Kişisel faktörler, kişilerin kendisi ile ilgili olan yaş, cinsiyet, eğitim durumu gibi değişkenlerdir. İş imkânı, çevresel bir faktör olarak üzerinde en çok durulan bir değişkendir (Iverson, 1999). İş piyasasında arz ve talebin süreklilik göstermesi, çalışanların sektörler arası veya işletmeler arası geçişlerine imkân sağlamıştır. Çalışanların daha iyi imkânlar sunan başka işletmeler bulması veya şirketlerin daha iyi elemanlar keşfetmesi durumunda çalışanların gönüllü veya zorla işten çıkma ihtimalini yükseltmiştir (Mueller, Price, Boyer ve Iverson, 1994). Son olarak iş tatmini, örgütsel bağlılık ve ayrılma niyeti, konu ile ilgili akademisyenler tarafından çalışanların uyumu ile ilgili faktörler olarak ele alınmıştır (Iverson, 1999).

\section{Araştırma Amacı ve Hipotezleri}

\subsection{Araştırmanın Amac1}

$\mathrm{Bu}$ araştırmanın temel amacı, Türk Polis Teşkilatı mensuplarının örgütsel bağlllık, iş tatmini ve işten ayrılma niyeti değerlerinin Polis Meslek Yüksekokulu (PMYO) ve Polis Meslek Eğitim Merkezi (POMEM) mezunları arasında anlamlı bir farklılık gösterip göstermediğinin 
Kula, S., Taşdöven, H., \& Dönmez, M. (2015). Eğitimin, mesleki tecrübenin ve terfi imkanlarının iș tatmini, örgütsel bağlllık ve işten ayrılma niyeti üzerine etkisi: Güvenlik sektörü analizi. International Journal of Human Sciences, 12(1), 129-149. doi: $10.14687 /$ ijhs.v12i1.3134

araştırılmasıdır. Araştırmada ayrıca, meslekte geçirilen sure ve meslekte ilerleme (kariyer) imkânlarının is tatmini, örgütsel bağlılık ve isten ayrılma niyeti ile ilişkili olup olmadığını araştırmayı hedeflemektedir.

\subsection{Yükseköğrenimin İş Tatmini, Örgütsel Bağll11k Ve İşten Aytılma Niyetine Etkisi}

$\mathrm{Bu}$ çalışmada iş tatmini, örgütsel bağlllık ve işten ayrılma niyetinin üniversite mezunu olan ve olmayan polisler açısından farlılık arz edip etmediği araştırılmıştır. Üniversite eğitiminin polislik açısından, halkla etkili etkili iletişim, halkın farklı kesimlerine toleranslı davranma ve hatta yüksek performans gibi bir takım faydalarının bulunduğu savunulmaktadır. Diğer taraftan, üniversite eğitimli polislerin mesleğe ve teşkilata sadakatlerinin düşük olduğu ve uzun vadede örgütsel bağll1ıklarının azaldığı, meslek içinde ilerleme beklentilerinin karşılanmaması durumunda işten ayrılma eğiliminin arttı̆̆ üniversite eğitimli polisliğe karşı çıkanların görüşleri arasındadır (Jones vd., 2005).

Çalışanların işten ayrılma niyetini etkileyen değişkenlerden biri örgütsel bağlılıklarıdır. Çok güçlü olmamakla birlikte birçok araştırmada örgütsel bağlılık ve işten ayrılma niyeti arasında sürekli olarak olumsuz bir ilişki tespit edilmiştir (Griffeth vd., 2000). Diğer taraftan üniversite eğitimli polislerin düşük düzeydeki iş tatminlerinin örgütsel bağlllı̆̆1 olumsuz etkilediği tespit edilmiştir (Bragg, 1998). Konuya ilişkin yapılan araştırmalarda birbirinden farklı sonuçlar elde edilmiştir. Duran ve Çelik (2011) in araştırma bulguları eğitim durumunun örgütsel bağlllı̆̆1 olumlu etkilediğini, eğitim seviyesi ile paralel olarak örgütsel bağl1lı̆̆ın da arttığını göstermiştir. Avustralya polisleri üzerinde yapılan çalışmada ise üniversite eğitimi almış olmakla örgütsel bağllık arasında herhangi bir ilişki tespit edilememiştir (Jones vd., 2005). Gana polisinde yapılan çalışmada yükseköğrenimin düşük seviyede örgütsel bağlllığa neden olduğu bulunmuştur. Kaya (2007) ise araştırmasında, yüksek lisans ve daha üst seviye eğitime sahip olan polislerin daha düşük seviyede örgütsel bağlılık yaşadıklarını ortaya koymuştur. Örgütsel bağlılığın bir boyutu örgütün ücret politikaları ve çalışma şartları, yönetim özellikleriyle doğrudan orantılıdır. Bir örgütte, üniversite mezunu olmayan çalışanlar için yeterli kabul edilecek şartların üniversite mezunları açısından tatminkar düzeyde olmaması, yükseköğrenim mezunu çalışanların örgütle daha zayıf bağlar kurmalarına neden olacaktır. Bu çerçevede araştırmanın birinci hipotezi aşağıdaki gibi belirlenmiştir:

H1: PMYO’ dan mezun olan Emniyet Teşkilatı mensuplarının örgütsel bağlılık düzeyleri POMEM’ den mezun olan Emniyet Teşkilatı mensuplanının örgütsel bağll1ık düzeylerinden daha yüksektir. 
Kula, S., Taşdöven, H., \& Dönmez, M. (2015). Eğitimin, mesleki tecrübenin ve terfi imkanlarının iș tatmini, örgütsel bağlllık ve işten ayrılma niyeti üzerine etkisi: Güvenlik sektörü analizi. International Journal of Human Sciences, 12(1), 129-149. doi: $10.14687 /$ ijhs.v12i1.3134

Üniversite eğitimi ve iş tatmini ilişkisine dair literatürde birbiriyle çelişen araştırma sonuçları bulunmakla birlikte, genel olarak üniversite eğitimi ile iş tatmini arasında negatif bir ilişki olduğu söylenebilir. Özellikle yapılan iş için gerekli yetkinliklerin, çalışanların eğitim durumu ve becerilerinin altında olduğu durumlarda bu iki değişken arasındaki negatif ilişki daha belirgin hale gelmektedir. Bu durumun, üniversite eğitimli çalışanların meslekten beklentiliyle ilişkili olduğu kaydedilmektedir. İyi eğitimli çalışanların işten beklentileri yüksek olmakta bu beklentiler karşılanmadığında ise iş tatminsizlĭgi ortaya çıkmaktadır (Balci, 2011). Regoli (1976) yükseköğrenimin polis karamsarlığına etkisini araştırdığı çalışmasında, üniversite mezunu polislerin meslektaşlarına kıyasla daha karamsar olduklarını bulmuştur. Profesyonel niteliklere sahip olan bu polislerin bu yeteneklerini pratikte kullanamamaları ve mesleğin alt kademe çalışanlar için öngördügü katı kurallara ve düzenlemelere maruz kaldıklarından iş tatminsizliği ve karamsarlık yaşadıklarını kaydetmektedir. Üniversite eğitimli polislerin amirlerinden daha az talimat alma ve daha çok inisiyatif kullanma eğiliminde oldukları ortaya konmuştur. Gerçekte durumun bu olmaması halinde ise iş tatmininde azalma yaşanmaktadır (Trojanowicz and Nicholson, 1976).

Konuyla ilgili yapılan ampirik çalışmalar, birbirinden farklı sonuçlar bulmuştur. Buzawa (1984) devriye polislerinin eğitim seviyesinin iş tatminini olumlu yönde etkilediğini tespit etmiştir. Türkiye'de yapılan araştırmalardan Yiğit, Dilmaç ve Deniz (2011)'in Konya ili polis teşkilatında yapmış olduğu araştırmada yükseköğrenim ile iş tatmini arasında pozitif bir ilişki olduğu bulunmuştur. Aksu (2012) ve Duran ve Çelik (2011) in araştırmalarında da benzer sonuçlar elde edilmiş, eğitim durumu yükseldikçe iş tatmininin de arttığı sonucuna ulaşılmıştır. Birçok çalışmada ise üniversite eğitimi ile iş tatmini arasında anlamlı bir ilişki tespit edilmemiştir (Baştemur, 2006; Griffin, Dunbar and McGill, 1978; Şanlı ve Akbaş, 2009; Özel vd., 2009). Dantzker (1992) üniversite eğitimli polislerin daha yükssek iş tatmini yaşadıklarını bulmuş ancak beş yıldan fazla görev yapan polislerde bu durumun tersine döndüğünü ve eğitim seviyesi ile iş tatmini arasındaki ilişkinin negatif hale geldiğini belirlemiştir. Balcı (2011) nın araştırmasında polislerin üniversite mezunu olma durumları ile iş arkadaşlarından memnuniyet ve terfi imkanlarından memnuniyet arasında negatif bir ilişkinin mevcut olduğu belirlenmiştir. İş tatmininin diğer elementleri ile eğitim düzeyi arasında ise bir ilişki tespit edilmemiştir. Görüldüğü gibi polislerin eğitim seviyesinin iş tatminini ne şekilde etkilediği ile ilgili tutarlı bulgular olmamakla birlikte, yaptığı işin gerektirdiğinden fazla eğitim ve yeteneğe sahip çalışanların bir süre sonra o işten tatmin olmamaya başlayacakları değerlendirilmektedir (Burris, 1983). Bu doğrultuda araştırmanın ikinci hipotezi aşağıdaki şekilde oluşturulmuştur: 
Kula, S., Taşdöven, H., \& Dönmez, M. (2015). Eğitimin, mesleki tecrübenin ve terfi imkanlarının iș tatmini, örgütsel bağlllık ve işten ayrılma niyeti üzerine etkisi: Güvenlik sektörü analizi. International Journal of Human Sciences, 12(1), 129-149. doi: $10.14687 /$ ijhs.v12i1.3134

H2: PMYO' dan mezun olan Emniyet Teşkilatı mensuplarının iş tatmin düzeyleri POMEM' den mezun olan Emniyet Teşkilatı mensuplarının iş tatmin düzeylerinden daha yüksektir.

Polis teşkilatlannda üniversite eğitiminin işten ayrllma niyetine etkisinin incelendiği az sayıda ampirik çalışmanın sonuçları genellikle yükseköğrenimin işten ayrıma niyetini artırdığı yönündedir. Bu bağlamda, Weirman'ın (1978) araştırmasında üniversite mezunu polislerin diğer polislere nazaran üç kat daha fazla meslekten ayrilma eğilimi gösterdikleri bulunmuştur. Benzer şekilde, Murray (2000) üniversite mezunu polislerin üniversite diplomasına sahip olmayanlara göre çok daha yüksek oranda işi bırakma eğiliminde olduklarını belirtmektedir. Aynı çalışmada, mesleğe girdikten sonra üniversite eğitimi alan polislerin genellikle mesleği bırakma temayüllerinden dolayı eğitim aldıkları sonucuna ulaşılmıştır. Araştırma bulguları, üniversite mezunu polislerin aldıkları eğitim polislik dışında başka meslekleri yapmaya da elverişli olduğundan, bu durumun meslekler arası hareketliliği tetiklediği ve polislik mesleğinde kalma eğilimi azalttığ1 yönündedir. Diğer taraftan, işten tatmin olmama, meslekten ayrilma düşüncesini ortaya çıkarmakta ve çalışanı yeni bir iş bulabilme ihtimalini değerlendirmeye sevk etmektedir. Aynı zamanda, bu işten ayrılmanın bedeli olarak mevcut işten ayrılma durumunda kaybedilecek maddi ve manevi değerler de hesap edilmektedir. Alternatif iş olanaklarının araştırılması ve değerlendirilmesinde, gerek o dönemde genel olarak iş bulabilme olanakları, gerekse kişinin eğitim durumu ve becerileri etkili rol oynamaktadır. Bu durumda, genel iş olanakları değişkeni üniversite mezunu olan ve olmayan polisler için eşit olmakla birlikte kişisel faktörlerin üniversite mezunu polislerin lehine avantaj oluşturacağı açıktır (Trevor 2001). Yukarıdaki argümanlar göz önünde bulundurularak araştırmanın üçüncü hipotezi aşağıdaki şekilde oluşturulmuştur:

H3: PMYO' dan mezun olan Emniyet Teşkilatı mensuplarının işten ayrılma niyetleri POMEM' den mezun olan Emniyet Teşkilatı mensuplarının işten ayrılma niyetlerinden daha düşük seviyededir.

\subsection{Tecrübe, Yükselme İmkânı ile İş Tatmini, Örgütsel Bağlılı ve İşten Ayrılma Niyeti Arasındaki İlişki}

Literatürde meslekte geçirilen yılın (tecrübenin) personelin örgüte olan bağlllığını arttırdığ1 ve iş tatminini artırdığı, işten ayrılma niyetini ise azalttığı belirtilmektedir (Meyer ve Allen, 1991). Yine personele işle ilgili sunulan yükselme ve ilerleme imkânlarının da personelin örgüte bağlllı̆̆ını ve iş tatminlerini pozitif yönde etkilediği (Gibson vd., 1973) işten ayrılma niyetlerini ise azalttığ1 çeşitli çalışmalar ile ortaya konulmuştur. Bu doğrultuda, meslekte geçirilen sürenin, 
Kula, S., Taşdöven, H., \& Dönmez, M. (2015). Eğitimin, mesleki tecrübenin ve terfi imkanlarının iş tatmini, örgütsel bağlllık ve işten ayrılma niyeti üzerine etkisi: Güvenlik sektörü analizi. International Journal of Human Sciences, 12(1), 129-149. doi: $10.14687 /$ ijhs.v12i1.3134

sunulan ilerleme imkânlarının personelin iş tatmin düzeyleri, örgüte bağlllık düzeyleri ve işten ayrılma niyetlerine etkisini araştırmak için aşağıdaki hipotezler geliştirilmiştir.

H4: Emniyet Teşkilatı mensuplarının meslekte geçirdikleri süre ile iş tatminleri arasında pozitif doğrusal bir ilişki vardır.

H5: Emniyet Teşkilatı mensuplarının meslekte geçirdikleri süre ile örgüte bağlılıkları arasında pozitif doğrusal bir ilişki vardır.

H6: Emniyet Teşkilatı mensuplarının meslekte geçirdikleri süre ile işten ayrılma niyetleri arasında negatif doğrusal bir ilişki vardır.

H7: Emniyet Teşkilatı mensuplarına sunulan ilerleme imkanları ile iş tatminleri arasında pozitif doğrusal bir ilişki vardır.

H8: Emniyet Teşkilatı mensuplarına sunulan ilerleme imkanları ile örgüte bağl1lkları arasında pozitif doğrusal bir ilişki vardır.

H9: Emniyet Teşkilatı mensuplarına sunulan ilerleme imkanları ile işten ayrılma niyetleri arasında negatif doğrusal bir ilişki vardır.

\section{Yöntem}

\subsection{Evren ve Örneklem}

Araştırmanın evrenini Emniyet Teşkilatında çalışan PMYO ve POMEM mezunu polis memurları oluşturmaktadır. Lise eğitimi sonrası 9 aylık polis okulu eğitimi almış olan polis memurları ile polis amirleri araştırma kapsamına dâhil edilmemiştir. Çalışma için Türkiye’nin yedi coğrafi bölgesini temsilen her coğrafi bölgesinden bir il seçilmiştir. Bu illerde çalışan POMEM ve PMYO mezunu polis memuru sayısı ile orantılı olarak örneklem seçilmiştir.

\subsection{Veri Toplama Araçları}

Meyer ve Allen (1997) tarafindan geliştirilen ve Wasti (2000) tarafindan Türkçeye uyarlanan 18 soruluk örgütsel bağllilk ölçeği, Spector (1985) tarafından geliştirilen iş tatmini ölçeğinin 9 sorudan oluşan kısa formu ve Walsh, Ashford ve Hill (1985) tarafindan geliştirilen 4 soruluk işten ayrılma niyeti ölçeği kullanılmıştır. Ölçeklerde yer alan sorularını cevaplamak üzere tamamı 'Kesinlikle Katılmıyorum’dan 'Tamamen Katıliyorum'a uzanan beşli Likert tipi olcek kullanılmıştır. Ölçekte ayrıca, meslekte ilerleme imkânlarına ve katılımcıların demografik özelliklerine dair sorular sorulmuştur. Örgütsel bağl1lık ölçeğinin güvenilirlik katsayısı (Cronbach’s Alpha) 0.914, iş tatmini ölçeğinin güvenilirlik katsayısı. 0.812 ve işten ayrılma niyeti ölçeğinin güvenilirlik katsayısı 0.824 olarak bulunmuş, bu da bu çalışma için kullanılan ölçeklerin güvenirlik düzeylerinin yeterli olduğunu göstermektedir. 
Kula, S., Taşdöven, H., \& Dönmez, M. (2015). Eğitimin, mesleki tecrübenin ve terfi imkanlarının iş tatmini, örgütsel bağlllık ve işten ayrılma niyeti üzerine etkisi: Güvenlik sektörü analizi. International Journal of Human Sciences, 12(1), 129-149. doi: $10.14687 /$ ijhs.v12i1.3134

\subsection{Verilerin Toplanmas1}

Hazırlanan anket internet ortamına aktarılmış ve anketin linki seçilen örneklemde yer alan polis memurlarının e-posta adreslerine gönderilmiştir. Araştırmaya katılmak tamamen gönüllük esasına göre yapılmış ve ilgili birimlerden gerekli izinler alınmıştır. Araştırmaya katılım oranını artırmak amacıyla belli aralıklarla e-postalar tekrar edilmiştir. Yaklaşı iki aylık süre sonunda çevrimiçi ortamda doldurulan anketler değerlendirmeye alınmıştır.

\subsection{Verilerin Analizi}

Araştırmanın amaçlarının istatistiksel olarak test edilmesi için t testi kullanılmıştır. Bu test tekniği, iki grup arasındaki ortalamanın istatistiksel olarak anlamlı bir şekilde farklılaşıp farklılaşmadığını belirlemek için kullanılan istatistiki bir metottur. Polis Meslek Yüksekokulu (PMYO) ile Polis Meslek Eğitim Merkezi (POMEM) mezunlarının örgütsel bağlılık, iş tatminleri ve işten ayrılma niyetlerinin birbirlerinden anlamlı bir biçimde farklı olup olmadığı $t$ testi uygulanmak suretiyle araştırılmıştır.

\section{Bulgular}

Bu bölümde araştırmaya katılanlardan elde edilen demografik veriler, PMYO ve POMEM mezunlarının örgütsel bağlllık, işten ayrılma niyetleri ve iş tatmine ilişkin elde edilen veriler ile bu verilerin korelasyon ve t testi analiz bulguları ele alınmaktadır.

\section{1. Demografik Bulgular}

Çalışmaya katılanlara ait tanımlayıcı bilgiler aşağıdaki tabloda (Tablo 1) sunulmuştur.

Tablo 1: Kat1lımc1ların Demografik Bilgileri

\begin{tabular}{|c|c|c|c|c|}
\hline & & $\overline{\mathrm{N}}$ & $\%$ & $\overline{\mathrm{K} \%}$ \\
\hline \multirow[t]{10}{*}{ Çalışılan İl } & Adana & 37 & 9,4 & 9,6 \\
\hline & Diyarbakır & 88 & 22,3 & 32,4 \\
\hline & İstanbul & 125 & 31,7 & 64,8 \\
\hline & İzmir & 46 & 11,7 & 76,7 \\
\hline & Malatya & 37 & 9,4 & 86,3 \\
\hline & Samsun & 19 & 4,9 & 91,2 \\
\hline & Yozgat & 34 & 8,6 & 100,0 \\
\hline & Toplam & 386 & 98,0 & \\
\hline & Eksik & 8 & 2,0 & \\
\hline & Toplam & 394 & 100,0 & \\
\hline \multirow{4}{*}{$\begin{array}{l}\text { Mezun Olunan Polis } \\
\text { Eğitim Kurumu }\end{array}$} & Polis Meslek & 216 & & 54.8 \\
\hline & Yüksekokulu (PMYO) & 210 & 54,8 & 54,8 \\
\hline & $\begin{array}{l}\text { Polis Meslek Ĕ̈itim } \\
\text { Merkezi (POMEM) }\end{array}$ & 178 & 45,2 & 100,0 \\
\hline & Toplam & 394 & 100,0 & \\
\hline \multirow[t]{3}{*}{ Yaş } & 25 Yaş ve Aşağısı & 99 & 25,1 & 25,1 \\
\hline & 26-30 Yaş Arası & 177 & 44,9 & 70,1 \\
\hline & 31-35 Yaş Arası & 73 & 18,5 & 88,6 \\
\hline
\end{tabular}


Kula, S., Taşdöven, H., \& Dönmez, M. (2015). Eğitimin, mesleki tecrübenin ve terfi imkanlarının iș tatmini, örgütsel bağlllık ve işten ayrılma niyeti üzerine etkisi: Güvenlik sektörü analizi. International Journal of Human Sciences, 12(1), 129-149. doi: 10.14687/ijhs.v12i1.3134

\begin{tabular}{llccc}
\hline & & 33 & 8,4 & 97,0 \\
& 46-40 Yaş Arasi & 12 & 3,0 & 100,0 \\
& Toplam & 394 & 100,0 & \\
\hline \hline Medeni Durum & Evli & 176 & 44,7 & 44,7 \\
& Bekâr & 218 & 55,3 & 100,0 \\
& Toplam & 394 & 100,0 & \\
\hline \hline
\end{tabular}

Tablo 1'den de anlaşılacağı ve beklendiği üzere katılımcıların yaklaşık \%30’u İstanbul ilinde çalışan personelden oluşmaktadır (125, \%31,7). Diyarbakır ilinde görev yapan 88 personel de araştırmaya önemli ölçüde katkı sağlamışlardır (\%22,3). Araştırmaya katılanların \%54,8’i Polis Meslek Yüksekokulu (PMYO) mezunu iken \%45,2’i ise Polis Meslek Eğitim Merkezi (POMEM) mezunudur. Katılanların yarısına yakınının (\%44,9) 26-30 yaşları arasında olduğu görülmektedir. Araştırmaya katılanların medeni durumları ile ilgili soruya verdikleri cevaplar incelendiğinde 218 $(\% 55,3)$ personelin bekâr, $176(\% 44,7)$ personelin ise evli olduğu anlaşılmaktadır.

\subsection{PMYO-POMEM Mezunlan Örgütsel Bağlılık, İsten Ayrılma Niyetleri Ve İş Tatmini Değerleri t Test Analizi}

Aşağıdaki tabloda (Tablo 2) PMYO VE POMEM mezunlarının örgütsel bağlılık, iş tatminleri ve işten ayrilma niyetleri arasındaki istatistiksel olarak anlamlı fark bulunup bulunmadığının anlaşılması için yapılan t testi sonuçları yer almaktadır. PMYO VE POMEM mezunlarının örgütsel bağlılık, iş tatmini ve işten ayrılma niyetleri arasındaki farkların istatistiksel olarak anlamlı olup olmadığını, yapılan analiz sonucunda bir değer olarak ortaya çıkan anlamlılık (Sig. (2-tailed)) değerinden anlayabiliriz. Bu değerin 0,05'den küçük olması iki grup arasında anlamlı bir farkın olduğunu göstermektedir.

Tablo 2: PMYO Ve POMEM Mezunları İçin Bağımsız İki Örneklem t Testi Sonuçları

Levene Testi t-testi

\begin{tabular}{|c|c|c|c|c|c|c|}
\hline & $\mathrm{F}$ & $\mathrm{P}$ & $\mathrm{t}$ & sd & $p$ & Ortalamalar Fark1 \\
\hline \multirow[t]{2}{*}{ Örgütsel Bağlılık } & 2,52 & ,113 & 2,079 & 392 & ,038 & , 17377 \\
\hline & & & 2,059 & 361,134 & 040 & ,17377 \\
\hline \multirow[t]{2}{*}{ İşten Ayrilma Niyeti } & 4,29 & ,039 & 2,172 & 392 &, 030 &,- 22329 \\
\hline & & & 2,152 & 361,890 & 032 &,- 22329 \\
\hline \multirow[t]{2}{*}{ İş Tatmini } & 3,72 & 054 & 1,327 & 392 & , 185 & , 10959 \\
\hline & & & 1,311 & 356,567 & , 191 & ,10959 \\
\hline
\end{tabular}

$\mathrm{p}<0,05$ 
Kula, S., Taşdöven, H., \& Dönmez, M. (2015). Eğitimin, mesleki tecrübenin ve terfi imkanlarının iș tatmini, örgütsel bağlllık ve işten ayrılma niyeti üzerine etkisi: Güvenlik sektörü analizi. International Journal of Human Sciences, 12(1), 129-149. doi: $10.14687 /$ ijhs.v12i1.3134

Örgütsel bağlllık ile işten ayrılma niyetlerine ilişkin anlamlllık değerleri 0,05’ ten küçük olduğundan (.038; .032) PMYO ve POMEM mezunlarının örgütsel bağlllık ve işten ayrılma niyetleri arasındaki farkın anlamlı bir fark olduğu anlaşılmaktadır. Bu anlamlı farkın bulunmasından sonra Tablo 1 deki örgütsel bağlılık ile işten ayrılma niyetlerine ilişkin değerlerin yorumlanması mümkün olmaktadır. İş tatminine ilişkin anlamlılık değeri $(0,185) 0,05$ ten büyük olduğu için PMYO ve POMEM mezunlarının iş tatmin düzeyleri arasında anlamlı bir farkın olmadığı anlaşılmaktadır. Bu sonuçlar doğrultusunda $\mathrm{H} 1$ ve $\mathrm{H} 3$ kabul edilmiş, $\mathrm{H} 2$ ise reddedilmiştir.

\subsection{Tecrübe ve Mesleki İletleme İmkânları İle Örgütsel Bağll11k, İşten Ayrılma Niyetleri ve İş Tatmini Değerleri Arasındaki Korelasyon Analizi}

Literatürde meslekte geçirilen y1lın örgüte bağl1lı̆ğ ve iş tatminini arttırdığ1, işten ayrilma niyetini ise azalttığı belirtilmektedir (Meyer ve Allen, 1991). Yine kişilere sunulan yükselme ve ilerleme imkânlarının da örgüte bağlılığ1 ve iş tatminini arttırdığı (Gibson vd.,1997), işten ayrılma niyetini ise azalttığı çeşitli çalışmalar ile ortaya konulmuştur. Belirtilen hususların bu çalışmada da geçerli olup olmadığını test etmek için araştırmaya katılanların örgütsel bağlılık, iş tatmini ve işten ayrılma niyetleri ile tecrübeleri ve kendilerine sunulan amirliğe geçiş ve ilerleme imkanları arasındaki korelasyon değerlerine bakılmıştır. Tablo 3 bu değişkenlere ilişkin korelasyon değerlerini göstermektedir.

Tablo 3: Değişkenler Arası Korelasyon Analizi

\begin{tabular}{|c|c|c|c|c|c|}
\hline & & & $\begin{array}{l}\text { Örgütsel } \\
\text { Bağlılık }\end{array}$ & $\begin{array}{c}\text { İşten Ayrılma } \\
\text { Niyeti }\end{array}$ & İş Tatmini \\
\hline \multirow{2}{*}{ GENEL } & İंlerleme İmkân1 & Pearson $r$ & "258 & 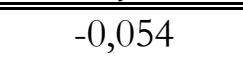 & 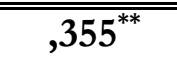 \\
\hline & Tecrübe & Pearson $\mathrm{r}$ & $-0,015$ & $-0,087$ & 0,02 \\
\hline \multirow{2}{*}{ PMYO } & İlerleme İmkân1 & 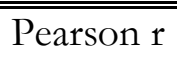 & ",300** & "-0,077 & 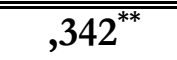 \\
\hline & Tecrübe & Pearson $r$ & 0,076 & $-0,043$ & 0,048 \\
\hline \multirow{2}{*}{ POMEM } & "İlerleme İmkân1 & Pearson $\mathrm{r}$ & 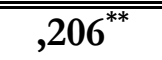 & "-0,018 & ",368** \\
\hline & Tecrübe & Pearson $r$ &,$- 191^{*}$ & $-0,101$ & $-0,047$ \\
\hline
\end{tabular}

$\mathrm{N}=394 * \mathrm{p}<0,05 * * \mathrm{p}<0,01$

Tablo 3' den de anlaşlacağı üzere araştırmaya katılan personele sunulan meslekte ilerleme imkânlarının genel anlamda tüm personelin örgüte olan bağl1lı̆̆ını ve iş tatminlerini arttırdığ1 görülmektedir. İşten ayrılma niyeti ile meslekte ilerleme değişkenleri arasında anlamlı bir ilişki tespit edilememiştir. Personelin çalışma süresi (tecrübe) ile personelin örgütsel bağlllık, iş tatminleri ve işten ayrılma niyetleri arasında anlamlı bir ilişki bulunmadığı görülmektedir. PMYO ve POMEM mezunu olan personel açısından ayrı ayrı bakıldığında ilişki güçleri değişkenlik arz 
Kula, S., Taşdöven, H., \& Dönmez, M. (2015). Eğitimin, mesleki tecrübenin ve terfi imkanlarının iș tatmini, örgütsel bağlllık ve işten ayrılma niyeti üzerine etkisi: Güvenlik sektörü analizi. International Journal of Human Sciences, 12(1), 129-149. doi: $10.14687 /$ ijhs.v12i1.3134

etmekle birlikte, genel analizdeki sonuçlarla paralel olarak ilerleme imkânları arttıkça iş tatmini ve örgütsel bağlılığın arttığı görülmektedir. Yine ayni şekilde işten ayrılma ve ilerleme imkânı değisskenleri arasında her iki grupta da ilişki tespit edilmemiştir. PMYO ile POMEM mezunları arasındaki fark meslekte gecen sure ile örgütsel bağlılık arasındaki ilişkide ortaya çıkmaktadır. POMEM mezunlarının tecrübeleri arttıkça örgüte olan bağlılıkları anlamlı bir şekilde azalmaktadır.

Meslekte geçirilen sürenin artması ile personelin örgütsel bağll1ıkları, iş tatminleri ve işten ayrılmaları arasında anlamlı bir ilişki bulunamadığından, H4, H5, H6, H9 reddedilmiştir. Araştırma sonuçlanı $\mathrm{H} 7$ ve H8' i desteklemektedir.

H6 ile ilgili sonuçlar incelendiğinde tecrübeleri artan POMEM mezunlarının örgüte bağlılığı anlamlı bir şekilde azaldığı dikkat çekici bir unsur olarak karşımıza çıkmaktadır.

\section{Tartışma}

Araştırmanın sonuçlanı üniversite eğitimi almış polislerin örgütsel bağlılık seviyelerinin üniversite eğitimi almayanlara göre daha düşük olduğunu göstermiştir. Örgütsel bağlllık teorisyenleri, örgütsel bağl1llğı etkileyen bireysel faktörleri incelerken içinde eğitim düzeyinin de yer aldığı demografik değişkenler ile başarı arzusu ve katılımcı değerlerin etkili rol oynadığını belirtmektedirler (Wasti, 2002). Araştırma bulguları bu teorik varsayımla tutarlı sonuçlar ortaya koymaktadır. Üniversite eğitimi almış polislerin diğer polislere nazaran daha düşük seviyede örgütsel bağlılık gösterdikleri görülmektedir. Üniversite mezunlarının aldıkları eğitim dolayısıyla daha fazla başarı elde etme duygusuna sahip olmaları ve daha katılımcı değerlere sahip olmaları muhtemeldir. Aldıkları eğitim doğrultusunda başarı elde etme ve yönetime katılma noktasında beklentileri karşılanmadığında emniyet örgütüne olan bağlılıklarının azalmış olması doğaldır.

Örgütsel bağlllı̆̆1 etkileyen örgüt yapısına ilişkin değerler arasında söz konusu örgütün yapısı, işleyişi, büyüklüğü, çalışma saatlerinin esnekliği ve ücretlendirme sistemleri sayılmaktadır James ve Hendry (1991) de polislik mesleğinin kendi tabiatından ziyade, polis örgütü içerisindeki çalışma şartlarının örgütsel bağlılık ve işten ayrılma niyetini etkilediğini bildirmektedir. POMEM mezunlarının düşük örgütsel bağl1lı göstermelerinin adı geçen örgütsel faktörle de ilişkili olduğu değerlendirilmektedir. Emniyet örgütünün diğer kamu örgütlerine kıyasla çalş̧ma saatlerinin yoğun oluşu, hiyerarşik bir yapıya sahip olması ve ücretlendirmenin eğitime ve çalışma saatlerine ciddi esneklik göstermiyor olması POMEM mezunlarının örgüte olan bağlılığını düşürmüş olması kuvvetle muhtemeldir. Örgütün yönetim tarzını benimsemedikleri Güvenlik Eğitimi Araştırma Merkezi (2011) tarafından yapılan 'Polis temel eğitiminde sorunlar ve çözüm önerileri’ raporunda şu şekilde ifade edilmiştir: 'POMEM mezunları amirlerinin emirlerini, hareketlerini ve idarecilik 
Kula, S., Taşdöven, H., \& Dönmez, M. (2015). Eğitimin, mesleki tecrübenin ve terfi imkanlarının iș tatmini, örgütsel bağlllık ve işten ayrılma niyeti üzerine etkisi: Güvenlik sektörü analizi. International Journal of Human Sciences, 12(1), 129-149. doi: $10.14687 /$ ijhs.v12i1.3134

tarzlarını yorumlama ve eleştirel bir bakış açısıyla değerlendirme yoluna gitmektedirler' (s.11). Yine aynı araştırmada kendilerini farklı bir yere koydukları ve polis memuru olduklarını hatırdan çıkardıkları belirtilmektedir ki, bu durum da onların meslekte hak ettiklerini düşündükleri statüyü elde edemedikleri düşüncesinde olduklarını göstermektedir. Dolayısıyla örgüte karşı bir devam bağımlılı̆̆1 oluşmamaktadır.

Çalış1lan örgüt içindeki rollere ve rol çatışmasına ilişkin faktörlerin de örgütsel bağllliğın düzeyini belirlediği tespit edilmiştir. Az sayıda da olsa, POMEM mezunlarının kendileri gibi üniversite mezunu olan amirleriyle kendilerini statü açısından eşdeğer olarak algılamaları meslekte rol çatışmasına yol açmakta ve netice itibariyle düşük örgütsel bağlllık yaşamalarına neden olmaktadır. PMYO mezunları ise lise eğitiminden sonra doğrudan polis olmak üzere eğitim aldıklarından bu tür örgütsel faktörlerden daha az etkilenmiş görünmektedirler.

Araştırmanın diğer önemli bir bulgusu üniversite eğitimi almış polislerin işten ayrılma niyetlerinin üniversite mezunu olmayanlara göre daha yüksek olduğudur. Teorik olarak alternatif iş olanaklarına sahip olan çalışanların bu olanaklara sahip olmayanlardan daha fazla meslekler arası hareketliliğe sahip olacakları, dolayısıyla işten ayrıma niyetlerinin yüksek olacağı iddia edilmektedir (Griffeth vd., 2000). Araştırma sonuçları bu teorik varsayımı doğrular niteliktedir. POMEM mezunu polisler esasen polislik haricinde bir meslek edinmek üzere üniversite eğitimi almış durumdadırlar. Ancak, bitirdikleri üniversite ile ilgili alanda hâlihazırda yeterli kadro açılmaması nedeniyle, alternatif bir meslek olarak, polisliği seçmekte ve kendi asli mesleklerinde yeterli iş imkânlarının oluşması durumunda polislikten ayrılma bir seçenek olarak yer almaktadır. POMEM mezunları için mevcut olan alternatif iş imkanı PMYO mezunları için bulunmamaktadır. Çünkü PMYO ön lisans mezunu olan polislerin bu eğitimle başvurabilecekleri iş olanağ1 son derece sınırlıdır. Araştırmanın bulguları, alternatif iş olanaklarının varlı̆̆ı, işi bırakma eğilimini artıracaktır tezi ile tutarlıdır. Jones vd. (2005) üçte biri ceza adaleti konusunda üniversite eğitimi almış olan bir örneklem üzerinde yapmış olduğu araştırmada, üniversite mezunu olan ve olmayanlar arasında işten ayrılma niyetleri arasında bir farklılık olmadığını bulmuştur. Bu sonuçlara göre, diplomaları meslek dışındaki bir işe uygun olmayanların işten ayrılma niyeti açısından üniversite mezunu olmayanlarla farklılaşmadığı tespit edilmiştir.

Araştırmanın iş tatminine ilişkin bulguları incelendiğinde, genel itibariyle POMEM ve PMYO mezunlarının iş tatmin ölçeğinden almıs olduğu puan ortalamalarının yüksek olmadığ1 göze çarpmaktadır. Üniversite eğitiminden bağımsız olarak her iki gruptaki polis memurlarının orta seviyede bir iş tatmini yaşadıkları görülmektedir. PMYO ve POMEM mezunları arasında iş tatmini açısından istatistiki olarak anlamlı bir fark olmadığı görülmektedir. Araştırma bulguları, 
Kula, S., Taşdöven, H., \& Dönmez, M. (2015). Eğitimin, mesleki tecrübenin ve terfi imkanlarının iș tatmini, örgütsel bağlllık ve işten ayrılma niyeti üzerine etkisi: Güvenlik sektörü analizi. International Journal of Human Sciences, 12(1), 129-149. doi: $10.14687 /$ ijhs.v12i1.3134

eğitim durumu ile iş tatmini arasındaki ilişkinin zayıf olduğunu bulan araştırmalarla paralellik arz etmektedir (Glisson ve Durick, 1988; Agho vd., 1993). Türkiye'de polisler üzerinde yapılan iş tatminine dair çalışmalardan Kayseri (Baştemur, 2006), Adana (Şanlı ve Akbaş, 2009) ve Kütahya (Özel vd., 2009) emniyet müdürlüklerinde yapılan araştırmalar eğitim durumunun polislerin iş tatmin düzeyini etkilemediğini göstermiştir. Araştırmamızın bulguları da üniversite eğitimi almış olmanın iş tatminini olumlu ya da olumsuz etkilemediğini göstermiştir. Balcı'nın (2011) araştırmasında ise eğitim düzeyinin iş tatmininin bileşenlerinden sadece terfi olanaklarından memnuniyet ve iş arkadaşlarından memnuniyeti negatif yönde etkilediği yönündedir. Analiz sonuçları, POMEM mezunlarının daha az iş tatmini yaşadıklarına işaret etmekle birlikte, iki grup arasındaki bu fark anlamlı değildir.

Araştırmadan elde edilen bu sonuçları birkaç farklı etkene bağlamak mümkündür. Ankete katılanların yaş ortalamasını Y kuşağı yaş ortalamasına yakın olması genel olarak bir tatminsizlik yaşanmasını açıklamaya yardımcı olabilir. Araştırmalar Y kuşağı çalışanlarının kontrol ve otoriteyi reddettiklerini ve kolaylıkla işten ve hayattan tatmin olmadıklarını ortaya koymaktadır (Keleş, 2011). Araştırmanın verileri $X$ kuşağı ile karşılaştırma imkânı vermediğinden ileriki araştırmalarda, elde edilen genel tatminsizlik durumunun bu kuşağa özgü olup olmadığ1 incelenmelidir. Diğer taraftan, emniyet örgütü içerisinde çok çeşitli branşlar, şubeler ve görevler bulunmasına rağmen, farklı eğitim sevilerindeki çalışanların tatminsizlik yaşamaları polislerin tatmin olacakları alanlarda istihdam edilememiş olabileceğini göstermektedir.

Polis memurlarına sunulan meslekte ilerleme imkânlarının personelin iş tatmin düzeyini ve aynı zamanda örgüte olan bağlılı̆̆ını arttırdığı görülmektedir. Dantzker (1992) de emniyet örgütündeki çalışma koşullarının iyileştirilmesi ve terfi olanaklarının artıılmasının çalışanların örgüte bağlılığını artıracağını ve örgütte kalmalarını sağlayacağı sonucuna ulaşmıştır.

Çalışmanın dikkat çekici bulgularından birisi POMEM mezunlarının tecrübeleri arttıkça örgüte olan bağl11ıklarının azaldığı olarak karşımıza çıkmaktadır. Bu husus, üniversite mezunu olan POMEM mezunlarının tecrübe kazandıkça kendi mezun oldukları bölüm ile ilgili başka arayışlar içerisine girmeye başladığ şeklinde izah edilebilir.

\section{Sonuç}

Araştırma sonuçları, 4 yıllık üniversite eğitiminin araştırma konusunu oluşturan üç kavramdan ikisini olumsuz etkilediğini göstermiştir. Üniversite eğitimi, polislerin örgütsel bağlllik düzeylerini azaltırken işten ayrılma niyetlerini de artırmıştır. İş tatmini açısından ise üniversite eğitiminin bir farklılık oluşturmadığı sonucuna varılmıştır. Bu bulgular doğrultusunda emniyet örgütü insan kaynakları politikası ele alındığında, Emniyet Teşkilatının üniversite mezunlarını 
Kula, S., Taşdöven, H., \& Dönmez, M. (2015). Eğitimin, mesleki tecrübenin ve terfi imkanlarının iș tatmini, örgütsel bağlllık ve işten ayrılma niyeti üzerine etkisi: Güvenlik sektörü analizi. International Journal of Human Sciences, 12(1), 129-149. doi: $10.14687 /$ ijhs.v12i1.3134

POMEM eğitimi sonrasında teşkilatta istihdam etme politikasını tekrar gözden geçirmesinin yaralı olacağı değerlendirilmektedir. Dünyanın farklı ülkelerinde polisliğe alım aşamasında üniversite eğitimi almış olma şartı aranmasının gerekli olup olmadığı oldukça tartışmalıdır. Bugün itibariyle ABD polis teşkilatlarının sadece \% 1 i polisliğe girişte üniversite eğitimi şartını aramaktadır (Bruns, 2010). Nitekim Wierman (1978) üniversite mezunlarının çok daha fazla meslekten ayrılma eğilimi gösterdiğini tespit etmiş ve polislik mesleğine girişte üniversite eğitiminin gerekli olmadığını savunmuştur. Dahası, bu sonuçlar üniversite eğitiminin polis memurları için gerekli olanın üzerinde bir eğitim seviyesi olduğuna işaret etmektedir. Mesleği icra etmek için gerekenden fazla eğitim alınmış olması ise örgütsel bağl1lı̆̆1 düşürmekte, meslekten ayrılma ve almış olduğu eğitime uygun bir işte çalışma düşüncesine sevk etmektedir. Dolayısıyla örgüte bağll1ık seviyesi düşük, işten ayrılma niyetinde olan çalışanların yüksek bir motivasyonla çalışmaları ve yüksek performans göstermeleri beklenemez.

$\mathrm{Bu}$ araştırma ise üniversite eğitiminin örgütsel bağlllık ve işten ayrılma eğilimi açısından daha olumsuz sorunlar doğurduğunu ortaya çıarmıştır. Bu çerçevede, polislerin mutlaka üniversite eğitimli olması hedefleniyor ise üniversitelerde açllacak kamu güvenliği, iç güvenlik, ceza adaleti gibi fakültelerden mezun olacak adayların polisliğe kabul edilmesi yerinde olacaktır. Mevcut sistemde başka bir mesleği icra etmek üzere üniversite eğitimini tamamlayan adayların polisliğe kabulü bir süre sonra meslekten ayrllma düşüncesini geliştirmekte ve bu düşünceyi sürekli taze tutmaktadır.

Emniyet Teşkilatı içerisinde yapısal değişikliğe gidilmeksizin kısa vadeli iyileştirmeler yapılmasının da iş tatmini ve örgütsel bağlllığı olumlu yönde etkileyeceği değerlendirilmektedir. Bunu yapabilmek için kişilerin aldıkları eğitimin seviyesi, eğitim aldıkları alan ile çalışanların bilgi ve becerilerinin dikkate alınarak ilgili birimlerde istihdam edilmeleri durumunda iş tatmini ve örgütsel bağlıllğ yükselteceği ve işten ayrılma eğilimini azaltacağ1 değerlendirilmektedir. Bunun yanı sıra, meslekte ilerleme imkânlarının genişletilmesinin de örgütsel tutumlar açısından olumlu etki yapacağı değerlendirilmektedir.

Her araştırmada olduğu gibi bu çalışmanın da bir takım sınırlılıkları mevcuttur. Ankete katılanlar, sorulan sorulara kendi iradeleri doğrultusunda serbest olarak cevap vermişlerdir. Katılanların sorulara ne derece gerçekçi cevaplar verdiklerini ölçme imkânı bulunmamaktadır. Ankete katılanların, olanı birebir yansıtmak yerine olması gerekeni göz önünde bulundurarak formda işaretleme yapmış olmaları ihtimali araştırmanın sınırlılıklarından biridir. Türk Polis Örgütünü temsil edebilmek amacıyla Türkiye'nin yedi bölgesinden yedi il seçilmiştir. Örneklemin 
Kula, S., Taşdöven, H., \& Dönmez, M. (2015). Eğitimin, mesleki tecrübenin ve terfi imkanlarının iș tatmini, örgütsel bağlllık ve işten ayrılma niyeti üzerine etkisi: Güvenlik sektörü analizi. International Journal of Human Sciences, 12(1), 129-149. doi: $10.14687 /$ ijhs.v12i1.3134

Türk polisindeki polis memuru popülasyonunu temsil ettiğini varsayılmaktadır. Bu varsayımın geçerliliği istatistiki olarak test edilmediği için bir sınırllık olarak not edilmelidir.

Bu araştırmada ele alınan kavramlar arasındaki sebep sonuç ilişkilerinin varlığı veya niteliği araştırma kapsına alınmamıştır. Örneğin, iş tatmini ve örgütsel bağl1lı̆̆ın işten ayrıma niyetini etkileyip etkilemediği, etkiliyor ise ne yönde etkilediği ileriki araştırmalara bırakılmıştır. Polisliğe girmeden önce iş tecrübesi olanların, iş dünyasıyla olan bağları alternatif iş olanaklarına ulaşmasını kolaylaştırarak işten ayrılma eğilimlerini artırıyor olabilir. Bu araştırmanın verileri bunu test etmeye uygun olmadığından ileriki çalışmalarda ele alınmalıdır.

\section{Kaynakça}

Abbasi, Sami M. and Kenneth W. Hollman, (2000), “Turnover: The Real Bottom Line”, Public Personnel Management, Vol. 2, ss. 333-342

Agho, Augustine O; Charles W. Mueller and James L. Price, (1993), "Determinants of employee job satisfaction: An empirical test of a causal model", Human Relations, Vol. 46, S. 8, ss.1007-1027.

Aksu, Nedim, (2012), “İş Tatmininin Bazı Demografik Değişkenler Açısından İncelenmesi”, Polis Bilimleri Dergisi, Vol. 14, S. 1, ss. 59-79.

Balc1, Fatih, (2011), "The effects of education on police officer job satisfaction: The case of Turkish National Police" International Journal of Human Sciences, Vol. 8, S. 2,

Baştemur, Yakup, (2006), "İş Tatmini İle Yaşam Tatmini Arasındaki İlişkiler: Kayseri Emniyet Müdürlüğü'nde Bir Araştırma”, Basılmamış Yüksek Lisans Tezi, Erciyes Üniversitesi,

Bateman, Thomas S. and Stephen Strasser, (1984), "A Longitudinal Analysis of Antecedents of Organizational Commitment”, Academy of Management Journal, Vol. 27, S.1, ss. 95-112.

Bayram, Levent, (2005), "Yönetimde Yeni Bir Paradigma: Örgütsel Bağlllık", Sayıstay Dergisi, S. 59, ss. 125-139.

Bilgin, Rıfat; Emhan, Abdurrahim ve Bez, Yasin, (2011), "Sosyal Hizmet Kurumu Çalışanlarında İş Memnuniyeti, Tükenmişlik ve Depresyon: Diyarbakır İli Alan Araştırması", Elektronik Sosyal Bilimler Dergisi, Vol. 10, S. 38, ss. 210-228.

Bragg, Deborah, (1998), "Job Satisfaction, Organisational Commitment and Higher Education: A study of Queensland Police”, Unpublished PhD dissertation, Queensland University of Technology Brisbane.

Bragger, Jennifer DeNicolis; Ofelia Rodriguez-Srednicki; Eugene J. Kutcher; Lisa Indovino and Erin Rosner, (2005), "Work-Family Conflict, Work-Family Culture, and Organizational Citizenship Behavior Among Teachers", Journal of Business and Psychology, Vol. 20, S. 2, ss. 303-324.

Brief, Arthur P, and Stephan J. Motowidlo, (1986), "Prosocial organizational behavior" Academy of Management Review, Vol. 11, S. 4, ss. 710-725.

Brough, Paula and Rachael Frame, (2004), "Predicting Police Job Satisfaction and Turnover Intentions: The Role of Social Support and Police Organizational Variables", New Zealand Journal of Psychology, Vol. 33, S. 1.

Bruns, Diana, (2010), "Reflections from the One-Percent of Local Police Departments with Mandatory Four-Year Degree Requirements For New Hires: Are They Diamonds in the Rough?", Southwest Journal of Criminal Justice, Vol. 7, S. 1, ss. 87-108.

Burris, Val, (1983), "The social and political consequences of overeducation", American Sociological Review, Vol. 48, No. 4, ss. 454-467. 
Kula, S., Taşdöven, H., \& Dönmez, M. (2015). Eğitimin, mesleki tecrübenin ve terfi imkanlarının iș tatmini, örgütsel bağlllık ve işten ayrılma niyeti üzerine etkisi: Güvenlik sektörü analizi. International Journal of Human Sciences, 12(1), 129-149. doi: 10.14687/ijhs.v12i1.3134

Buzawa, Ewa S, (1984), "Determining Patrol Officer Job Satisfaction: The Role of Selected Demographic and Job Specific Attitudes", Criminology, Vol. 22, S. 1, ss. 61-81.

Clegg, C. W, (1983), "Psychology of employee lateness, absence, and turnover: A methodological critique and an empirical study", Journal of Applied Psychology, Vol.68, ss. 88-101.

Cohen, Aaron, (1993), "Organizational Commitment and Turnover: A Meta-Analysis", The Academy of Management Journal, Vol. 36, S. 5, ss. 1140-1157.

Cotton, John L and Jeffrey, M Tuttle, (1986), "Employee Turnover: A Meta-Analysis and Review with Implications for Research", The Academy of Management Review, Vol. 11, S. 1, ss. 55-70.

Dantzker, M L, (1992), "An Issue for Policing-Educational Level and Job Satisfaction: A Research Note", American Journal of Police, Vol. 12, S. 2, ss. 101-118.

Duran, Haci ve Mucahit, Çelik, (2011), "Demografik Özelliklerin Örgütsel Bağlllık ve İş Tatmini Üzerindeki Etkileri: Adıyaman Emniyet Müdürlügü Örneğì", E-Journal of New W orld Sciences Academy, Vol. 6, S. 2, ss. 396-414.

Firth, Lucy; David J. Mellor; Kathleen, A Moore and Claude, Loquet, (2004), "How can managers reduce employee intention to quit?", Journal of Management Psychology, Vol. 19, S. 2, ss. $170-187$.

Gibson, James, L ; John M, Ivancevich and James H, Donnelly, (1973), "Organizations: Structure, Processes, Behavior", Michigan; Business Publications.

Glisson, Charles and Mark, Durick, (1988), "Predictors of job satisfaction and organizational commitment in human service organizations", Administrative Science Quarterly, Vol. 33, S. 1, ss. 61-81.

Griffeth, Rodger W ; Pete,r W Hom and Stefan, Gaertner, (2000), "A meta-analysis of antecedents and correlates of employee turnover: Update, moderators' tests, and research implications for the millennium", Journal of Management, Vol. 26, S. 3, ss. 463-488.

Griffin, G. R; Dunbar, R. ve McGill, M, (1978), "Factors associated with job satisfaction among police personnel", Journal of Police Science and Administration, Vol. 6, S. 1, ss. 77-85.

Guimaraes, Tor, (1997), "Assessing employee turnover intentions before/after TQM", International Journal of Quality \& Reliability Management, Vol. 14, S. 1, ss. 46-63.

Güvenlik Eğitimi Araştırma Merkezi, (2011), "Polis Temel Eğitiminde Sorunlar ve Çözüm Önerileri: Proje Sonuç Raporu”, Ankara: Polis Akademisi Yayınlari.

Iverson, Roderick, D, (1999), "An Event History Analysis of Employee Turnover: The Case of Hospital Employees in Australia”, Human Resource Management Review, Vol. 9, S. 4, ss. 397 418.

James, Stephen and Bronwyn, Hendry, (1991), "The Money or the Job: The decision to leave policing”, Australia and New Zeland Journal of Criminology, Vol. 24, S. 3, ss. 69-89.

Jansen, Patrick G, M; Ada, Kerkstra; Huda, Huijer Abusaad ve Jouke, van der Zee, (1996), "The Effects of Job Characteristics and Individual Characteristics on Job Satisfaction and Burnout in Community Nursing", Journal of Nurse Study, Vol. 33, S. 4, ss. 407-421.

Jones, David; Liz, Jones and Timothy, James Prenzler, (2005), "Tertiary education, commitment, and turnover in police work", Police Practice and Research: An International Journal, Vol. 6, S. 1, ss. 49-63.

Kalliath, Thomas J and Alexandra, Beck, (2001), "Is the path to burnout and turnover paved by a lack of supervisory support: a structural equations test", New Zealand Journal of Psychology, Vol. 30, ss. 72-78.

Kaya, Onay, (2007), “Örgütsel Bağll11k: Emniyet Genel Müdürlüğü Merkez Biriminde Bir Uygulama”, Basılmamış Yüksek Lisans Tezi, Gazi Üniversitesi.

Keleş, Hatice Necla, (2011), "Y kuşağı çalışanlarının motivasyon profillerinin belirlenmesine yönelik bir araştırma", Organizasyon ve Yönetim Bilimleri Dergisi, Vol. 3, S. 2, ss.129-139. 
Kula, S., Taşdöven, H., \& Dönmez, M. (2015). Eğitimin, mesleki tecrübenin ve terfi imkanlarının iș tatmini, örgütsel bağlllık ve işten ayrılma niyeti üzerine etkisi: Güvenlik sektörü analizi. International Journal of Human Sciences, 12(1), 129-149. doi: 10.14687/ijhs.v12i1.3134

Kramer, Michael W ; Ronda, Roberts Callister and Daniel, B. Turban, (1995), "Informationreceiving and information-giving during job transitions", Western Journal of Communication, Vol. 59, S.2, ss. 151-170.

LePine, Jeffrey A; Amir, Erez and Diane, E. Johnson, (2002), "The Nature and Dimensionality of Organizational Citizenship Behavior: A Critical Review and Meta-Analysis", Journal of Applied Psychology, Vol. 87, S. 1, ss. 52-65.

Locke, E A, (1976), “The Nature and Causes of Job Satisfaction” in Ed. M.P. Dunnette, Handbook of Industrial and Organizational Psychology, Chicago: Rand McNally.

Maertz, C P and M, A Campion, (1998), "25 Years of Voluntary Turnover Research: A Review and Critique', International Review of Industrial and Organizational Psychology, Vol. 13, ss. 49-81.

Mano-Negrin, Rita and Shay, S Tzafrir, (2004), "Job Search Modes and Turnover", Career Development International, Vol. 9, S. 5, ss. 442-458.

Meyer, John P and Natalie, J Allen, (1997), Commitment in the workplace, Theory, research, and application, CA: Sage Publication.

Meyer, John P and Natalie, J Allen, (1991), "A Three Component Conceptualization of Organizational Commitment”, Human Resource Management Review, Vol. 1, S. 1, ss. 61-89.

Mowday, Richard T; Richard, M Steers and Lyman, W Porter, (1979), "The Measurement of Organizational Commitment", Journal of Vocational Behavior, Vol. 14, S. 2, ss. 224-247.

Mueller, Charles W; E Marcia Boyer; James, L. Price and Roderick, D. Iverson, (1994), "Employee Attachment and Noncoercive Conditions of Work: The Case of Dental Hygienists", Work and Occupations, Vol. 21, S. 2, ss. 179 - 212.

Murray, John, (2000), "Convenient Myths about Higher Education in Policing", Platypus Magazine, Australian Federal Police, Vol. 69, S. 9-11, ss. 37-39.

Ongori, Henry, (2007), "A Review of the Literature on Employee Turnover", African Journal of Business Mangement, Vol. 1, S. 3, ss. 49-54.

Özdevecioğlu, Mahmut, (2003), “Alg1lanan Örgütsel Destek ile Örgütsel Bağlllık Arasındaki İlişkilerin Belirlenmesine Yönelik Bir Çalışma”, Dokuz Eylül Üniversitesi İ̈BF Dergisi, Vol. 18, S. 2, ss. 113-130.

Özel, Ali; Bayındır, Nida; İnan, Hatice Zeynep ve Özel, Emine, (2009), "The effect of educational differences on the level of job satisfaction in police officers in Turkey" International Journal of Police Science and Management, Vol. 11, S. 3, ss. 358-365.

Peters, Lawrence H; Rabi, S Bhagat and Edward, J O'Connor, (1981), “An examination of the independent and joint contribution of organizational commitment and job satisfaction on employee intention to quit", Group Organization Management, Vol. 6, S. 1, ss. 73-82.

Price, James L, (1977), “The Study of Turnover”, Iowa: Iowa State University Press.

Regoli, Robert M. (1976), "The Effects of College Education on the Maintenance of Police Cynicism", Journal of Police Science and Administration, Vol. 4, S. 3, ss. 340-345.

Serinkan, Celalettin ve Bardakçı, Ahmet, (2007), "Pamukkale Üniversitesinde Çalışan Öğretim Elemanların İş Tatminlerine İlişkin Bir Araştırma", Selçuk Üniversitesi Karaman İI.B.F. Dergisi, , S.12, ss. 152-163.

Smith, M and Brough, P, (2003), "Personnel Recruitment and Selection" in Ed. O'Driscoll, M Taylor, P, Kalliath, T "Organizational Psychology in Australia and New Zealand", Melbourne: Oxford University Press.

Spector, Paul E. (1985), "Measurement of Human Service Staff Satisfaction: Development of the Job Satisfaction Survey" American Journal of Community Psychology, Vol. 13, S. 6, ss. 693-713.

Şanlı, Savaş ve Akbaş, Turan, (2009), "Adana İlinde Çalışan Polislerin İş Doyumu Düzeylerinin Bazı Değişkenler Açısından İncelenmesi”, Polis Bilimleri Dergisi, Vol. 11, S. 2, ss.73-86.

Trevor, Charlie O, (2001), "Interactions among actual ease-of-movement determinants and job satisfaction in the prediction of voluntary turnover", Academy of Management Journal, Vol. 44, S. 4, ss. 621-638. 
Kula, S., Taşdöven, H., \& Dönmez, M. (2015). Eğitimin, mesleki tecrübenin ve terfi imkanlarının iș tatmini, örgütsel bağlllık ve işten ayrılma niyeti üzerine etkisi: Güvenlik sektörü analizi. International Journal of Human Sciences, 12(1), 129-149. doi: 10.14687/ijhs.v12i1.3134

Trojanowicz, Robert C., and Thomas G. Nicholson (1976), “A Comparison of Behavioral Styles of College Graduate Police Officers", Police Chief, Vol. 43, S. 8, ss. 56-69.

Walsh, James P; Susan, J Ashford and Thomas, E Hill, (1985), "Feedback Obstruction: The Influence of the Information Environment on Employee Turnover Intention', Human Relations, Vol. 38, S. 1, ss. 23-46.

Wasti, S Arzu, (2002), "Affective and Continuance Commitment to the Organization: Test of an Integrated Model in the Turkish Context", International Journal of Intercultural Relations, Vol. 26, S. 5, ss. 525-550.

Wasti, S Arzu, (2000), "Meyer ve Allen’in üç boyutlu örgütsel bağlllık ölçeğinin geçerlilik ve güvenilirlik analizi” Teblĭg, 8. Ulusal Yönetim ve Organizasyon Kongresi, Nevşehir, 25-27 Mayis.

Weirman, C L, (1978), "Variances of ability measurement scores obtained by college and noncollege educated troopers" The Police Chief, Vol. 45, S. 8, ss. 34-36.

Yiğit, Ruhi ve Dilmaç, Bülent, (2011), "İş ve Yaşam Doyumu: Konya Emniyet Müdürlüğü Alan Araştırması", Polis Bilimleri Dergisi, Vol. 13, S. 3, ss. 1-18.

\section{Extended English Abstract}

Having a higher education in police force is a controversial and discussing issue in the law enforcement arena. Several arguments made by scholars and practitioners point out that university degree is not a required qualification for law enforcement officers to be possessed. Moreover, claiming that having a university degree results in dissatisfaction with the job, detachment from organizational goals, higher level of intent to leave is not rare (Murray, 2000). On the other hand, proponents of university degree for professional policing claim that the higher the education, the better understanding of the context of policing. Higher education plays an important role for the development of communication and problem solving skills, which seem to be necessary policing skills in the community policing era (Carter et al,

1989).

Turkish National Police (TNP) is one of the leading public organizations in Turkey that has indicated the outstanding improvements over the last decade. Increasing the educational levels of TNP employees is one of the important cornerstones of this improvement. In 2001, to become police officers, a two-year college degree, instead of nine months training, were mandated for high school graduates. TNP recruits unranked police officers from two different sources. First option is to accept university graduates to police training institutions and to provide them nine months training in Police Vocational Training Centers (POMEM). Second option is to provide 2-year degree programs to high school graduates in Police Vocational High Schools (PMYO). Both of POMEM and PMYO graduates serve as unranked police officers for TNP.

Law enforcement literature on this issue emphasizes the differences between degree holder and non-degree holder officers in terms of authoritarianism, use of excessive force and performance. Organizational attitudes of law enforcement personnel in terms of their holding degree are rarely studied. Therefore, this study aims to examine the impacts of higher education on organizational attitudes of law enforcement personnel, namely; job satisfaction, organizational commitment and turnover intention. The second research question this study sought to answer is to examine the effects of tenure and promotion opportunities provided by the organizations on 
Kula, S., Taşdöven, H., \& Dönmez, M. (2015). Eğitimin, mesleki tecrübenin ve terfi imkanlarının iș tatmini, örgütsel bağlllık ve işten ayrılma niyeti üzerine etkisi: Güvenlik sektörü analizi. International Journal of Human Sciences, 12(1), 129-149. doi: 10.14687/ijhs.v12i1.3134

Turkish National Police (TNP) members' perceived job satisfaction, organizational commitment and turnover intention levels.

In terms of representativeness of the sample, the sample was selected from seven cities, each representing one geographical region of Turkey on a random basis. The random selection of the sample from seven cities is one of the important strengths of the study. The final dataset of the study comprised 394 responses after deleting the some participant responses who had not completed the majority of the questions.

Findings of the study revealed that officers graduated from PMYO are more committed to and less likely to leave their organization than POMEM graduates. The education levels of TNP employees were not found to be statistically significant with their job satisfaction levels.

The finding that non-degree holder police officers (PMYO Graduates) are more committed to their organization is cocsistent with the study findings of Bragg (1998) and Kaya (2007). Another important finding of this study is that university degree holding police officers are more likely to have turnover intention than their non-university counterparts. The result is consistent with theoretical assumption that employees who have different job alternatives due to their degree are more likely to have job mobility than their counterparts who are less likely to have these opportunities (Griffeth et al., 2000; Murray, 2000). The finding of the study that education level of police officers is not significantly associated with thier job satisfaction levels is consistent with previous studies (Glisson ve Durick, 1988; Agho vd., 1993). Even though education level of TNP employees is not statistically significant with their job satisfaction levels, POMEM graduates express less job satisfaction compared to their PMYO counterparts.

Promotion opportunities provided by the TNP were forund to be statistically significant with job satisfaction and organizational commitment level of TNP employees. The more the promotion opportunities they have, the higher their job satisfaction and organizational commitment levels are. This finding is consistent with the findings of Dantzker (1992) indicating that better work conditions and promotion opportunities in law enforcement organizations result in increase in high organizational commitment and less intent to leave. Another impoartant finding of the study is that tenure plays an important role for POMEM graduates in terms of their commitment to their organization. Tenure was found to be statistically and negatively associated with the organizational commitment levels of TNP employees. Possible explanation of this would be that POMEM graduates may think to find alternative job opportunities as their tenure goes up.

The findings of the study illustrate a need for internal policy reform in how the executives of TNP organize their employment and human resource management policies. The first limitation of the study is related with the research design. Cross-sectional research is used by the researchers to test the research hypotheses. However, cross-sectional research has been questioned for lack of temporal precedence. Instead of cross-sectional research, longitudinal research could be preferred by the researchers to observe the change in the variables over time. 